\title{
OPTIMALISASI ZONA PEMANFAATAN WISATA TAMAN NASIONAL KARIMUNJAWA MELALUI KOMUNITAS IKAN KARANG (Optimizing The Tourism Utilization Zone Karimunjawa National Park through Coral Reef Fish Communities)
}

\author{
Rohmani Sulisyati $^{1 *}$, Erny Poedjirahajoe ${ }^{2}$, Lies Rahayu Wijayanti Faida ${ }^{2}$ dan Chafid Fandeli ${ }^{2}$ \\ ${ }^{1}$ Balai Taman Nasional Karimunjawa, Jl. Sinar Waluyo Raya no. 248 Semarang, 50273, Indonesia. \\ ${ }^{2}$ Fakultas Kehutanan, Universitas Gajah Mada, Jl. Agro Bulaksumur Yogyakarta 55281, Indonesia.
}

*Penulis korespondensi. Tel: 08122844912. Email: syifa.ilyas@ gmail.com.

Diterima: 27 Maret 2015

Disetujui: 28 Oktober 2015

\begin{abstract}
Abstrak
Wisata alam terkait erat dengan konservasi lingkungan sehingga dapat saling mendukung dan menguntungkan. Konservasi berhubungan dengan kondisi komunitas penyusunnya. Zona pemanfaatan wisata memerlukan komunitas ikan karang sebagai daya tarik wisata. Penelitian dilakukan dengan tujuan mengoptimalkan zona pemanfaaatan wisata Taman Nasional Karimunjawa untuk aktivitas wisata melalui komunitas ikan karang. Pengamatan dilakukan pada bulan November 2013, pada 14 lokasi. Pencatatan ikan dilakukan pada transek sabuk (belt transect) dengan teknik visual sensus, mencatat famili dan jumlah ikan yang ditemukan serta perkiraan panjang total ikan. Transek dilakukan pada dua kedalaman yaitu 3 dan 6-8 m untuk mewakili perairan dangkal dan dalam. Analisis kuantitatif dilakukan untuk melihat keragaman serta pengukuran nilai indeks keanekaragaman, keseragaman dan dominansi. Hasil pengamatan pada daerah dangkal dijumpai 18 famili ikan. Famili Chaetodontidae, Labridae dan Scaridae dapat dijumpai di seluruh lokasi. Perairan dangkal memiliki keanekaragaman ikan karang melimpah sedang dengan kondisi komunitas ikan tertekan stabil. Pada perairan dalam dijumpai 17 famili ikan. Famili Caesionidae, Chaetodontidae, Labridae dan Scaridae dapat dijumpai pada seluruh lokasi. Keanekaragaman jenis ikan melimpah sedang dengan kondisi komunitas ikan tertekan stabil. Pada perairan dangkal bagian luar sebelah barat kepulauan dihuni oleh kelompok ikan mayor dengan sedikit famili, sedangkan pada bagian tengah kepulauan dijumpai ikan beragam famili dan pulau terluar sebelah barat dan timur terdapat dominansi ikan. Pulau-pulau yang berada di tengah gugusan kepulauan sesuai untuk wisata snorkeling. Pada perairan dalam terbagi pulau-pulau dengan tutupan karang sedang dan ikan karang dari sedikit famili, tutupan karang kategori sedang dengan famili ikan melimpah, tutupan karang kategori baik tetapi famili ikan sedikit serta tutupan karang baik dan ikan beragam famili. Diving pemula dilakukan pada pulau-pulau dengan resiko penyelaman rendah dan sedikit famili, sementara untuk advanced dilakukan pada pulau-pulau dengan sumberdaya tinggi dan beragam famili ikan.
\end{abstract}

Kata kunci: aktivitas wisata, ikan karang, kelimpahan, komunitas, taman nasional.

\begin{abstract}
Ecotourism was closely related to environmental conservation that could be mutually supported and valuated. Conservation related with the communities condition. The tourism utilization zone required the coral reef fish communities as a tourist attraction. The aim of the study was optimized the tourist utilization zone Karimunjawa National Park for tourism activities through coral reef fish communities. Coral reef fish data collected on a belt transect by a visual census, record families and the number of fishes are found and the approximate total length of fish. The research conducted during November 2013 at 14 locations. The transect was deployed at two depth variations i.e 3 and 6-8 meters to represent the shallow and the deep water. Quantitative analysis was done to measure the fish abundance and diversity index, evenness index and domination. The result showed in the shallow water found 18 coral fish families. Chaetodontidae, Labridae and Scaridae can be found at all locations. Fish abundance is moderate which a condition of fish community depressed to stable. While the deep water, there were 17 families. Caesionidae, Chaetodontidae, Labridae, and Scaridae can found in all locations. Fish abundance is moderate which a condition of fish community depressed to stable. In the shallow waters of the outer west island inhabited by a group of major fish with a little family; the center of the archipelago encountered diverse fish families and the outer islands west and east there is a dominance of fish. The islands were located in the middle of the islands suitable for snorkeling. In the deep waters were divided four groups of islands i.e. islands with fair coral cover and the few families of coral reef fish, islands which had a fair coral cover with abundant fish families, islands with good coral cover but little fish families and good coral cover and coral fish families diverse. Activity for beginners done on islands with low-risk dives and the few families coral reef fish, while for advanced done on islands with high resource and diverse coral reef fish families.
\end{abstract}

Keywords: abundance, communities, coral reef fish, national park, tourist activity. 


\section{PENDAHULUAN}

Terumbu karang Indonesia memiliki keanekaragaman tertinggi di dunia (Veron, 1993) dan menjadi satu negara di antara enam negara lainnya membentuk segitiga terumbu karang (coral triangle) yang terletak sepanjang garis katulistiwa. Terdapat lebih $75 \%$ species karang dari perkiraan 600 species karang dunia ditemukan di coral triangle (Veron, 2000). Luas tutupan karang lebih dari $30 \%$ dari luas tutupan terumbu karang dunia dan lebih dari 3.000 species ikan hidup di dalamnya (Green dkk., 2011). Indonesia dan Filipina memiliki $77 \%$ dari kawasan terumbu karang ini dan hampir $80 \%$ nya terancam (Burke dkk., 2002)

Ikan karang merupakan organisme penghuni terumbu yang jumlahnya relatif banyak dan mencolok bila dibandingkan biota lain sesama penghuni terumbu (Nybakken, 1993). Ikan dapat mempengaruhi interaksi komunitas terumbu karang, proses ekologi dan produksi (McClanahan, 2002). Komunitas ikan di ekosistem terumbu karang merupakan penyokong berbagai hubungan yang terjadi dalamnya.

Karimunjawa sebagai salah satu kawasan konservasi laut di Indonesia memiliki sumberdaya alam yang sangat potensial dengan tingginya keanekaragaman biota dan ekosistem yang relatif utuh dibandingkan wilayah lain di sepanjang Perairan Utara Jawa (Sulisyati dkk., 2014). Daya tarik utama kawasan ini terletak pada ekosistem terumbu karang dan ikan penghuni terumbu karang sebagai obyek wisata bahari. Wisata alam tergantung pada konservasi lingkungan yang baik sehingga dapat saling mendukung dan menguntungkan (Clayton, 2002), di mana konservasi berhubungan dengan kesehatan komunitasnya. Persoalan kerusakan yang dihadapi oleh kawasan konservasi laut secara umum disebabkan oleh aktivitas komersial dan rekreasi serta aktivitas perikanan (Salm dkk., 2000). Seiring dengan peningkatan jumlah wisatawan ke Karimunjawa, diperlukan penelitian yang terkait dengan keberadaan ikan karang penghuni terumbu pada lokasi wisata. Penelitian dilakukan dengan tujuan untuk mengoptimalkan zona pemanfaaatan wisata Taman Nasional Karimunjawa untuk aktivitas wisata melalui komunitas ikan karang.

\section{METODE PENELITIAN}

Lokasi pengamatan dilakukan di zona pemanfaatan wisata bahari Taman Nasional Karimunjawa terdiri dari 14 lokasi (Gambar 1). Lokasi meliputi perairan pulau-pulau Menjangan Besar, Menjangan Kecil, Menyawakan, Kembar, Tengah, sebelah timur Kumbang, Bengkoang bagian selatan, Cemara Besar bagian utara, Tanjung Gelam, Cemara Kecil bagian utara, Katang, Krakal Besar bagian selatan, Krakal kecil dan Cilik (sesuai dengan SK Dirjen PHKA no 28/IV-SET/2012 tanggal 6 Maret 2012). Penelitian dilakukan pada bulan November 2013.

Pengamatan ikan karang untuk mengetahui keragaman spesies ikan karang (Marnane dkk., 2003). Masing-masing titik dilakukan pada kedalaman 3 meter untuk mewakili kondisi terumbu karang di daerah dangkal dan 6-8 meter untuk kondisi terumbu karang di daerah dalam (English, dkk., 1997). Semua data ikan yang ditemui selama pengamatan digunakan untuk menghitung kelimpahan, kecuali famili Pomacentridae yang diabaikan untuk analisa. Ikan-ikan famili Pomacentridae merupakan komponen terbesar ikan karang namun tidak bernilai ekonomis (Muttaqin dkk., 2013) sehingga menimbulkan bias.

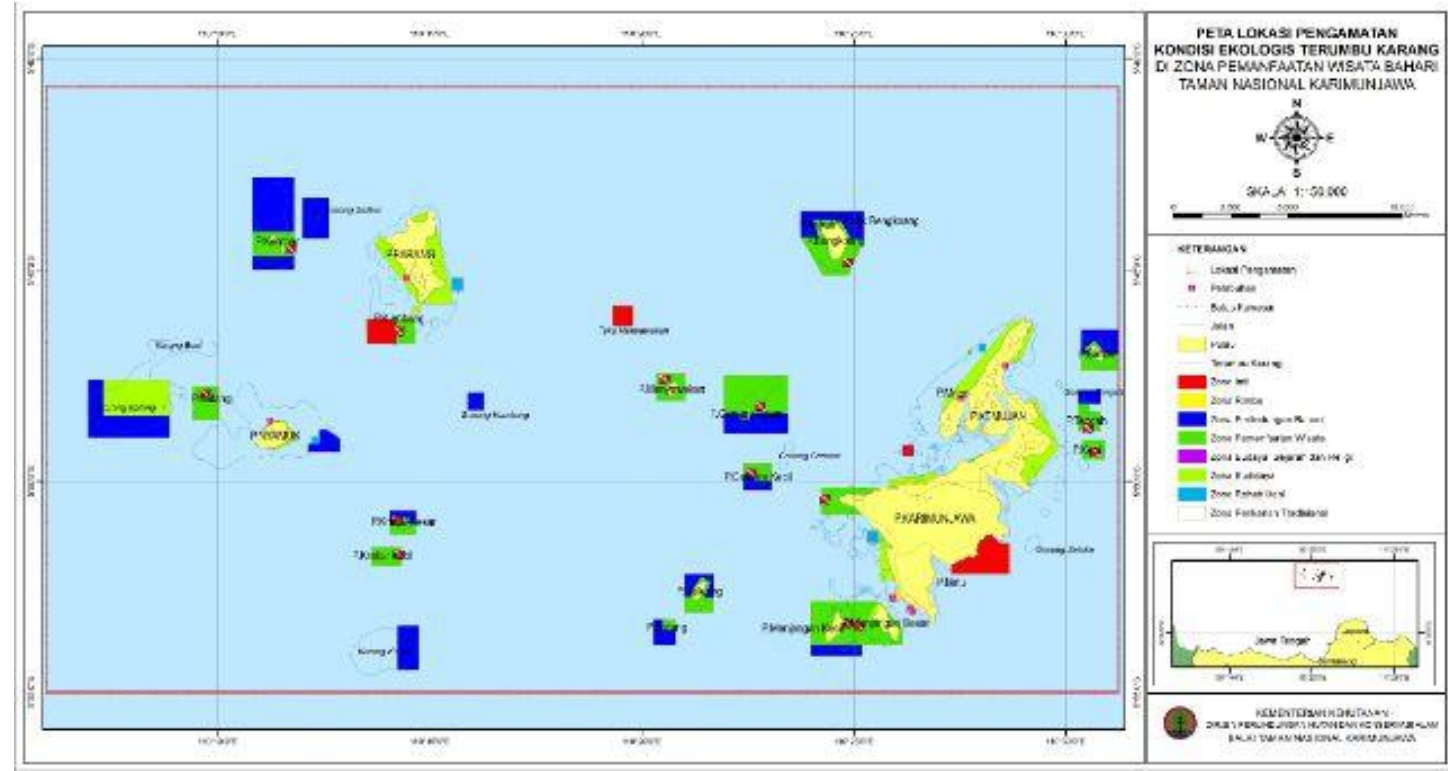

Gambar 1. Peta lokasi pengamatan ikan karang. 


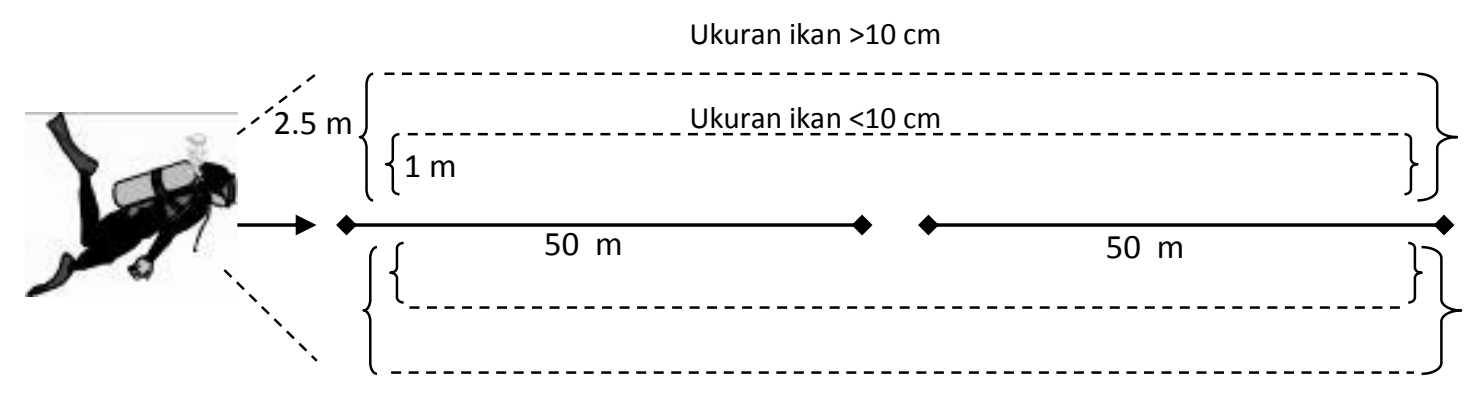

Gambar 2. Lebar transek untuk survei biomassa ikan karang.

Tabel 1. Famili ikan karang pada perairan dangkal zona pemanfaatan wisata Taman Nasional Karimunjawa.

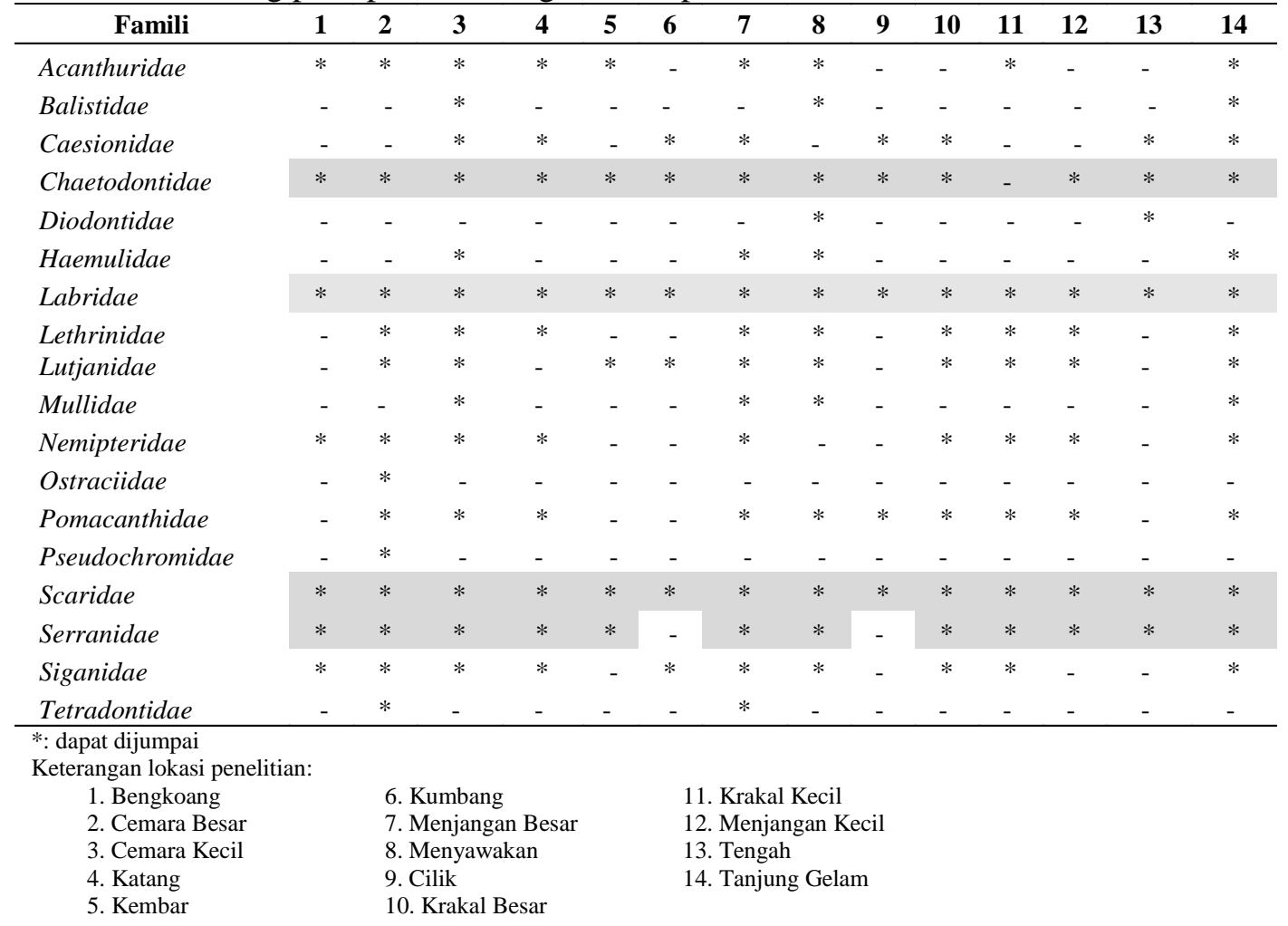

Teknik pencatatan menggunakan teknik visual sensus (Gambar 2), yaitu mencatat famili dan jumlah ikan yang ditemukan serta perkiraan panjang total ikan. Pengamatan dilakukan pada transek sabuk (belt transect) dengan ukuran (a) $2 \times(5 \times 50 \mathrm{~m})$ untuk ikan $>10 \mathrm{~cm}$ dan (b) $2 \times(2 \times 50 \mathrm{~m})$ untuk ikan $<10 \mathrm{~cm}$. Analisis data dengan menghitung indeks keanekaragaman dan kelimpahan ikan per kedalaman. Keanekaragaman jenis dianalisis dengan indeks keanekaragaman Shannon, indeks dominansi Simpson dan indeks kemerataan Pileou (Ludwig dan Reynold, 1988).

\section{HASIL DAN PEMBAHASAN}

Hasil pengamatan pada daerah dangkal dijumpai 18 famili ikan karang (Tabel 1). Ikan dari famili Chaetodontidae, Labridae dan Scaridae dapat dijumpai di seluruh lokasi pengamatan perairan dangkal. Famili Serranidae ditemukan di seluruh lokasi kecuali di pulau Kumbang dan Cilik. Famili Ostraciidae dan Pseudochromidae hanya dijumpai di pulau Cemara Besar. Famili Chaetodontidae merupakan indikator ekosistem terumbu karang. Labridae merupakan salah satu famili yang paling sering dijumpai di terumbu karang dan di pasir terbuka. Famili Serranidae termasuk dalam ikan predator dan piscivorus (Kuiter dan Tonozuka, 2001). Jenis ini biasanya hidup di area terumbu karang dan berlindung di celah-celah karang besar dan massive, biasanya jenis ini aktif di malam hari (nocturnal).

Kelimpahan ikan berdasarkan famili per hektar ditunjukkan pada Gambar 3. Kelimpahan ikan pada pulau Kumbang dan Menjangan Besar disusun famili Caesionidae. Famili ini biasanya menggerombol (schooling) di sekitar perairan dangkal yang kaya akan plankton. Di Karimunjawa, ikan dari famili ini merupakan target utama pada operasi muroami beberapa saat yang lalu (Muttaqin, 


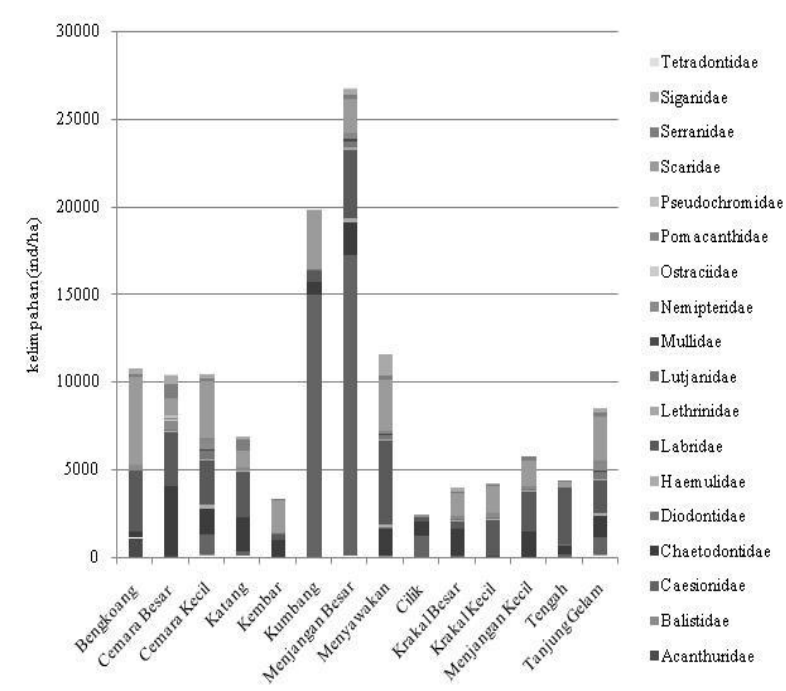

Gambar 3. Kelimpahan ikan (ind/ha) yang dijumpai pada perairan dangkal

dkk., 2013). Ikan Labridae ditemukan di seluruh lokasi pengamatan, termasuk herbivora terumbu karang, sehingga di mana ada terumbu karang ikan ini paling banyak ditemukan dan tersebar luas. Ikan herbivora dari famili Scaridae hidup secara berkelompok selama hidupnya.

Dari seluruh famili yang dijumpai kemudian dikelompokkan menjadi tiga kategori yaitu ikan target, ikan indikator dan ikan mayor (Adrim dkk., 2012). Hampir seluruh ikan yang dijumpai di pulau Bengkoang, Kumbang dan Krakal Kecil adalah ikan mayor. Terdapat indikasi keberadaan ikan mayor berhubungan dengan kondisi terumbu karang penyusunnya. Substrat dasar di pulau Bengkoang sebagian besar tersusun dari komponen abiotik berupa dead coral with alga (DCA) dan sebagian kecil softcoral bersama hardcoral. Substrat dasar pulau Krakal Kecil sebagian besar tersusun dari komponen abiotik berupa rubble dan DCA (Sulisyati dkk., 2014).

Kelompok ikan Chaetodontidae merupakan ikan karang yang berfungsi sebagai indikator biologis. Pengurangan dan ketidakhadiran populasinya dapat digunakan sebagai indikator penurunan kondisi karang. Kelompok ini lebih dikenal sebagai butterfly fish merupakan penghuni terumbu karang yang permanen, sebagai pemakan alga dan berfungsi sebagai pengontrol alga di terumbu karang. Alga dan planula karang merupakan biota yang menempel pada substrat sehingga berkompetisi dalam memperoleh ruang. Persentase kehadiran ikan indikator yang relatif kecil dijumpai di pulau Krakal Kecil (Tabel 2).

Penelitian yang dilakukan oleh Marsaoli (1998) menunjukkan bila semakin besar persentase karang hidup semakin tinggi pula densitas ikan Chaetodontidae karena memiliki kebiasaan makan
Tabel 2. Persentase komposisi kelompok ikan karang pada perairan dangkal.

\begin{tabular}{lrrr}
\hline \multicolumn{1}{c}{ Lokasi (\%) } & Target (\%) & Indikator $(\boldsymbol{\%})$ & Mayor $\mathbf{( \% )}$ \\
\hline Bengkoang & 2 & 5 & 93 \\
Cemara Besar & 15 & 61 & 24 \\
Cemara Kecil & 13 & 20 & 67 \\
Katang & 18 & 46 & 36 \\
Kembar & 3 & 31 & 67 \\
Kumbang & 1 & 4 & 96 \\
Menjangan Besar & 5 & 8 & 87 \\
Menyawakan & 10 & 23 & 67 \\
Cilik & 0 & 40 & 60 \\
Krakal Besar & 6 & 45 & 49 \\
Krakal Kecil & 8 & 0 & 92 \\
Menjangan Kecil & 12 & 44 & 44 \\
Tengah & 8 & 46 & 46 \\
Tanjung Gelam & 15 & 21 & 64 \\
\hline
\end{tabular}

Sumber : Hasil pengamatan.

multivar yaitu dapat mengkonsumsi berbagai komponen karang tidak terbatas hanya mengkonsumsi polip saja. Kelimpahan ikan kelompok ini selalu dihubungkan dengan kondisi karang yang belum banyak mengalami tekanan. Pada pulau Krakal Kecil ditemukan sedikit ikan indikator. Komposisi lifeform penyusun karang di pulau Krakal Kecil yang didominasi oleh substrat abiotik terutama rubble menunjukkan pada pulau ini terjadi tekanan ekologi. Komposisi lifeform pulau Bengkoang, Kumbang dan Menjangan Besar berpengaruh pada kehadiran ikan indikator yang rendah. Pulau Bengkoang memiliki substrat abiotik yang tinggi tersusun dari DCA dan soft coral (Sulisyati dkk., 2014). Pulau Menjangan Besar memiliki kelimpahan ikan tertinggi dari kelompok ikan mayor. Kelompok ikan ini menghabiskan seluruh fase kehidupannya di wilayah terumbu karang. Terumbu menjadi tempat mencari makan, berlindung sekaligus melakukan reproduksi. Penelitian oleh Sembiring (2011) membuktikan bahwa faktor yang mempengaruhi kelimpahan ikan adalah kompleksitas substrat yang berkaitan dengan ruang perlindungan ikan dan fisiologi dasar perairan. Distribusi spasial ikan-ikan karang dipengaruhi oleh pembentuk karang hidup, komponen pembentuk karang hidup yang berperan meliputi karang hidup, karang lunak dan komponen abiotik (Marsaoli, 1998).

Pengamatan terhadap panjang ikan diperlukan untuk mengetahui kelas ukuran ikan yang sering dijumpai di zona pemanfaatan wisata. Hal ini berhubungan dengan kemampuan regenerasi ikan. Ikan dengan ukuran lebih besar memiliki kemampuan regenerasi lebih baik, karena dapat menghasilkan telur lebih banyak (Muttaqin dkk., 2013). Gambar 4 menunjukkan ukuran ikan yang 
Tabel 3. Struktur komunitas ikan karang pada perairan dangkal.

\begin{tabular}{llcc}
\hline \multicolumn{1}{c}{ Lolasi } & H' $^{\prime}$ & E & C \\
\hline Bengkoang & 1,93 & 0,69 & 0,34 \\
Cermara Besar & 2,43 & 0,66 & 0,25 \\
Cemara Kecil & 2,83 & 0,74 & 0,19 \\
Katang & 2,34 & 0,70 & 0,25 \\
Kembar & 1,56 & 0,34 & 0,69 \\
Kumbang & 1,14 & 0,44 & 0,60 \\
Mergangan Bes ar & 1,85 & 0,57 & 0,40 \\
Menyawakan & 2,34 & 0,63 & 0,27 \\
Cilik & 1,62 & 0,70 & 0,38 \\
Krakal Besar & 2,21 & 0,67 & 0,28 \\
Krakal Kecil & 1,85 & 0,58 & 0,37 \\
Merjangan Kecil & 2,04 & 0,68 & 0,29 \\
Tergah & 1,32 & 0,51 & 0,57 \\
Targung Gelam & 2,93 & 0,77 & 0,18 \\
\hline
\end{tabular}

Sumber : Hasil analisis.

paling sering ditemukan di semua lokasi adalah ikan dengan ukuran 5-10, 10-15 dan 15-20 cm. Ikan ukuran 20-30 cm ditemukan di hampir seluruh lokasi kecuali pulau Bengkoang dan Kembar. Kelas ikan dengan ukuran $>40 \mathrm{~cm}$ tidak dijumpai di lokasi manapun. Ikan berukuran besar $(30-40 \mathrm{~cm})$ hanya dijumpai di pulau Katang, Menjangan Kecil dan Tanjung Gelam.

Tabel 3 memperlihatkan nilai indeks keanekaragaman $\left(\mathrm{H}^{\prime}\right)$ ikan karang pada lokasi dangkal berkisar antara 1,14-2,93. Berdasarkan kriteria indeks keanekaragaman jenis (Ludwig dan Reynold, 1988) semua lokasi pada perairan dangkal memiliki keanekaragaman ikan karang melimpah sedang $\left(1 \leq \mathrm{H}^{\prime} \leq 3\right)$. Indeks keseragaman (E) berkisar 0,34-0,77 menunjukkan komunitas ikan pada perairan dangkal berada pada kisaran yang tertekan hingga stabil. Pulau Kembar dan Kumbang menunjukkan komunitas tertekan $(0<\mathrm{E} \leq 0,5)$ dengan adanya dominasi. Famili Scaridae mendominasi Pulau Kembar dan famili Caesionidae mendominasi perairan Pulau Kumbang. Secara umum Pulau Kembar dan Kumbang memiliki tutupan karang keras dengan kategori baik namun komunitas ikan karangnya tidak beranekaragam (Sulisyati dkk., 2014). Pada lokasi dengan komunitas tertekan, perlu segera diketahui penyebab adanya tekanan terhadap komunitas. Bila tekanantekanan yang diterima terutama oleh aktivitas manusia dapat diminimalkan maka kondisi komunitas akan cepat kembali ke kondisi yang lebih baik (Anonim, 1999).

Hampir semua lokasi mempunyai kisaran nilai indeks keseragaman $(0,5<\mathrm{E} \leq 0,75)$, yang menunjukkan komunitas ikan karang labil. Komunitas ikan labil ditunjukkan oleh pulau-pulau Bengkoang, Cemara Besar, Cemara Kecil, Katang,

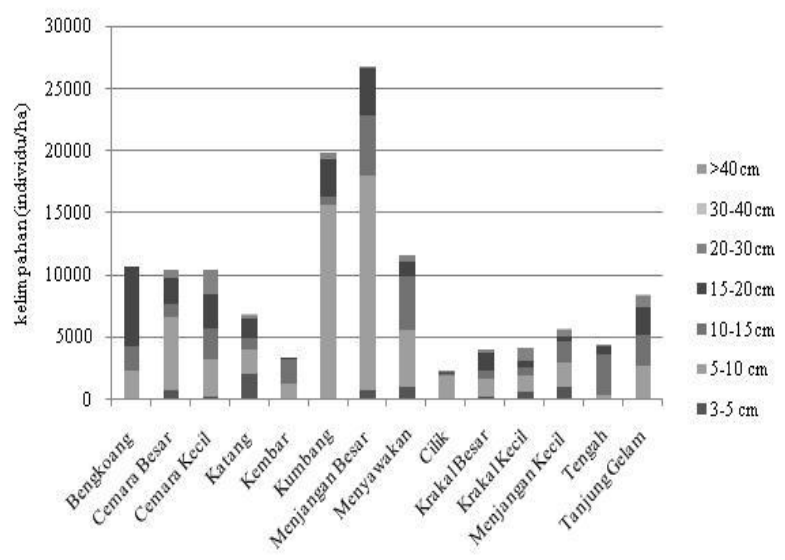

Gambar 4. Kelas ukuran ikan karang yang dijumpai pada perairan dangkal.

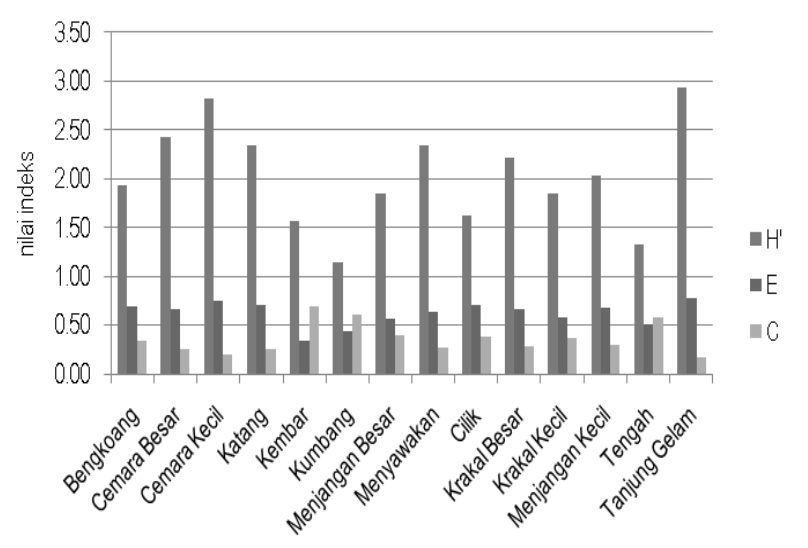

Gambar 5. Nilai indeks komunitas ikan pada perairan dangkal.

Menjangan Besar, Menyawakan, Cilik, Krakal Besar, Krakal Kecil, Menjangan Kecil dan Tengah. Pada pulau-pulau tersebut ditemukan famili yang bervariasi dengan kelimpahan ikan tinggi. Namun memiliki komposisi kelompok ikan yang tidak seimbang antara kelompok ikan mayor, indikator dan ikan target serta sebaran kelas ukuran ikan yang tidak merata. Hanya Tanjung Gelam yang memiliki nilai $\mathrm{E} 0,77(0,75<\mathrm{E} \leq 1)$ menunjukkan komunitas stabil dengan keseragaman jenis yang merata, tidak ada dominasi jenis tertentu. Kestabilan ini berkaitan dengan famili yang beragam, komposisi kelompok ikan dan sebaran kelas ukuran ikan yang merata.

Gambar 5 menunjukkan seluruh lokasi pengamatan memiliki indeks dominansi (C) berkisar antara 0,18-0,69. Nilai indeks terendah 0,18 pada lokasi Tanjung Gelam menunjukkan bahwa tidak ada dominansi jenis tertentu. Nilai 0,69 ditunjukkan oleh pulau Kembar dan nilai 0,60 oleh pulau Kumbang, mengindikasikan terdapat dominansi jenis ikan pada kedua pulau ini.

Pengamatan pada perairan dalam menunjukkan hasil terdapat 17 famili seperti tertera pada Tabel 4. Famili Caesionidae, Chaetodontidae, Labridae dan 
Tabel 4. Famili ikan karang pada lokasi perairan dalam zona pemanfaatan wisata.

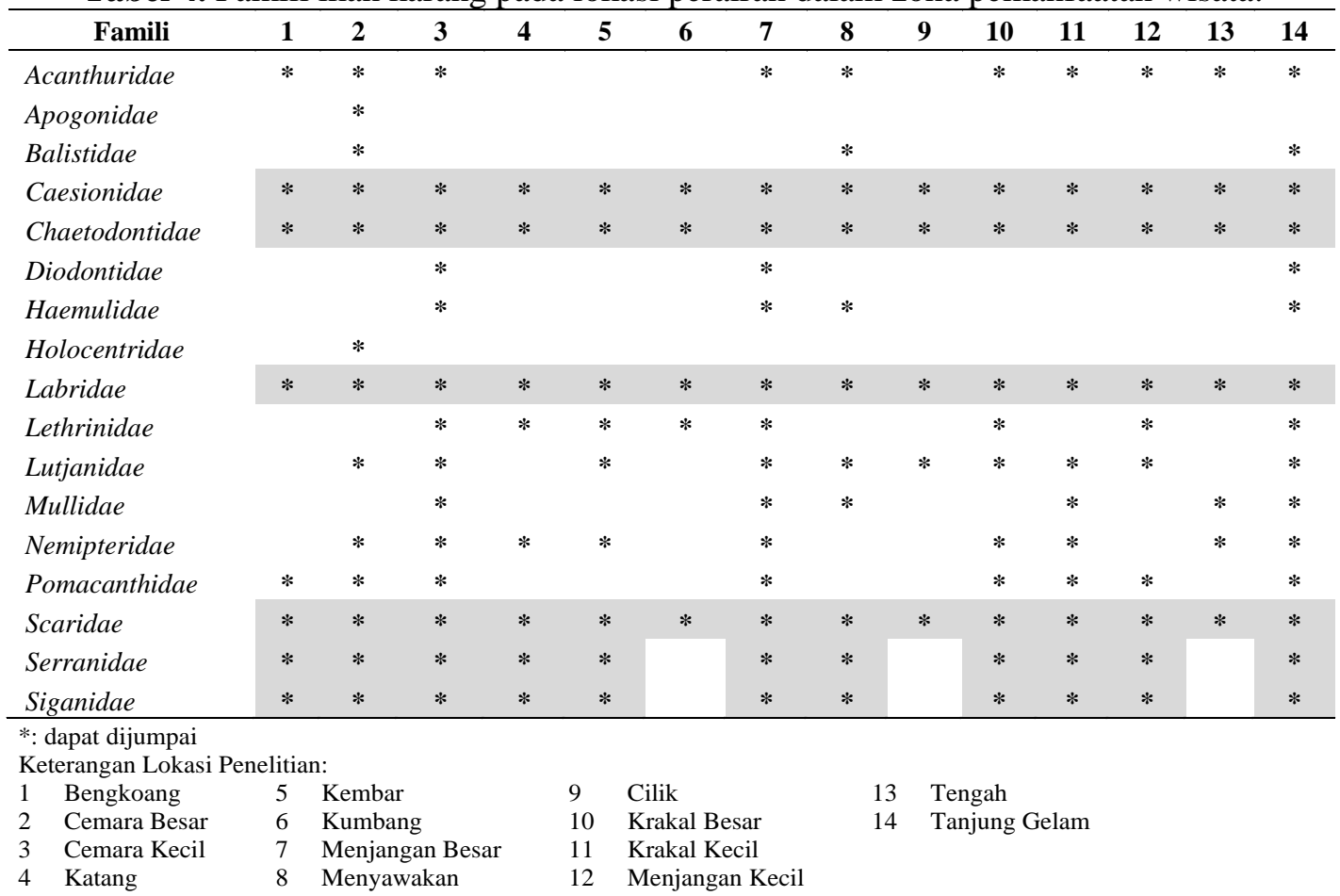

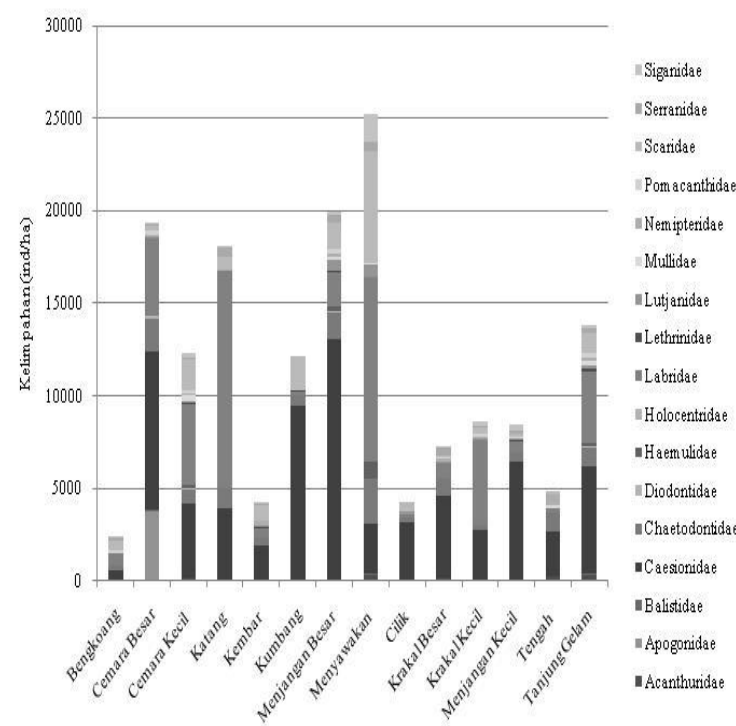

Gambar 6. Famili ikan pada perairan dalam zona pemanfaatan wisata.

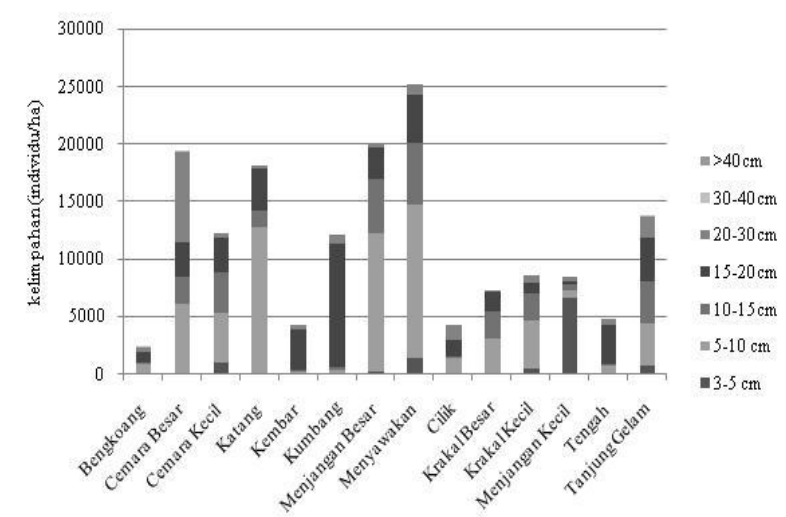

Gambar 7. Kelimpahan ikan karang pada perairan dalam berdasar kelas ukuran ikan.
Scaridae dapat dijumpai pada seluruh lokasi pengamatan. Famili Serranidae dan Siganidae hampir dijumpai pada seluruh lokasi namun tidak dijumpai di pulau Kumbang, Cilik dan Tengah. Famili Apogonidae dan Holocentridae hanya ditemukan di pulau Cemara Besar.

Kebanyakan dari ikan karang memiliki batas wilayah tersendiri dan sangat spesifik, menempati ruang dan sangat jarang keluar dari daerahnya sendiri untuk mencari makan dan menempati daerah perlindungan (Sembiring, 2011). Keanekaragaman yang tinggi dari ikan karang dipengaruhi oleh ruang terumbu karang (Marsaoli, 1998). Dengan ditemukannya famili Chaetodontidae, Labridae dan Scaridae pada seluruh lokasi pengamatan berkaitan dengan kebiasaan makan dari famili ini sebagai pemakan karang. Pemakan karang sangat tergantung pada jaringan hidup karang yang hanya terdapat pada struktur karang yang masih hidup. Ikan-ikan ini secara langsung memakan lendir (mисиs) karang yang bersimbiosis dengannya.

Kelimpahan ikan berdasarkan famili pada perairan dalam dapat dilihat pada Gambar 6 . Perairan pulau Menyawakan memiliki kelimpahan ikan tertinggi kemudian Menjangan Besar dan Cemara Besar. Kelimpahan Labridae paling banyak di pulau Menyawakan, sedangkan kelimpahan ikan terbesar di pulau Menjangan Besar dan Cemara Besar adalah famili Caesionidae. Bila dilihat dari substrat dasarnya, didominasi oleh komponen abiotik. Substrat dasar di pulau Menyawakan lebih dari $50 \%$ terdiri dari komponen abiotik yang terdiri dari sebagian besar DCA dan pasir. Karang hidup 
penyusun kebanyakan adalah karang non-Acropora masif dan menjamur dan sangat sedikit karang bercabang (Sulisyati, dkk., 2014). Kondisi ini sesuai dengan preferensi Labridae sebagai pemakan alga yang biasanya tumbuh dalam batuan keras berkapur yang ditumbuhi alga.

Kelimpahan ikan di pulau Menjangan Besar dan Cemara Besar terbanyak berasal dari famili Caesionidae. Ikan ini merupakan perenang aktif dan selalu ditemukan dalam gerombolan (schooling), namun mereka sering diam untuk menangkap zooplankton pada pertengahan perairan di atas terumbu. Pulau Bengkoang menunjukkan kelimpahan ikan terendah dan hanya dijumpai 8 famili.

Kelimpahan ikan tertinggi ada di pulau Menyawakan (Gambar 7) dengan kelas ukuran ikan terbanyak berurut-turut 5-10, 10-15 dan $15-20 \mathrm{~cm}$. Pulau Menjangan Besar dan Cemara Besar memiliki kelimpahan ikan relatif sama, dengan kelas ukuran yang berbeda. Pulau Menjangan Besar kelimpahan ikan pada kelas ukuran 5-10 cm. Cemara Besar dengan ikan ukuran 20-30 cm, pulau Kumbang kebanyakan ikan dengan ukuran 15-20. Pulau Menjangan Kecil dijumpai ikan berukuran kecil 3-5 $\mathrm{cm}$.

Indeks keanekaragaman (H') berkisar antara 1,04-2,51, semua lokasi pengamatan di perairan dalam mempunyai keanekaragaman sedang (Tabel 5 dan Gambar 8). Nilai indeks tertinggi di pulau Menyawakan dan Bengkoang. Pulau Menjangan memiliki kelimpahan ikan tertinggi dengan kelompok ikan mayor mendominasi. Pulau Bengkoang memiliki kelimpahan ikan paling rendah dengan sebaran perfamili serta komposisi kelompok ikan merata.

Tabel 5. Persentase komposisi kelompok ikan pada perairan dalam.

\begin{tabular}{lrrr}
\hline \multicolumn{1}{c}{ Lokasi } & Target (\%) & Indikator (\%) & Mayor (\%) \\
\hline Bengkoang & 10 & 13 & 78 \\
Cemara Besar & 1 & 12 & 87 \\
Cemara Kecil & 5 & 11 & 84 \\
Katang & 11 & 16 & 73 \\
Kembar & 6 & 12 & 82 \\
Kumbang & 0 & 5 & 94 \\
Menjangan Besar & 8 & 8 & 85 \\
Menjawakan & 15 & 16 & 69 \\
Cilik & 3 & 6 & 91 \\
Krakal Besar & 8 & 15 & 76 \\
Krakal Kecil & 5 & 6 & 89 \\
Menjangan Kecil & 5 & 6 & 89 \\
Tengah & 0 & 24 & 76 \\
Tanjung Gelam & 8 & 10 & 82 \\
\hline
\end{tabular}

Sumber : Hasil pengamatan.

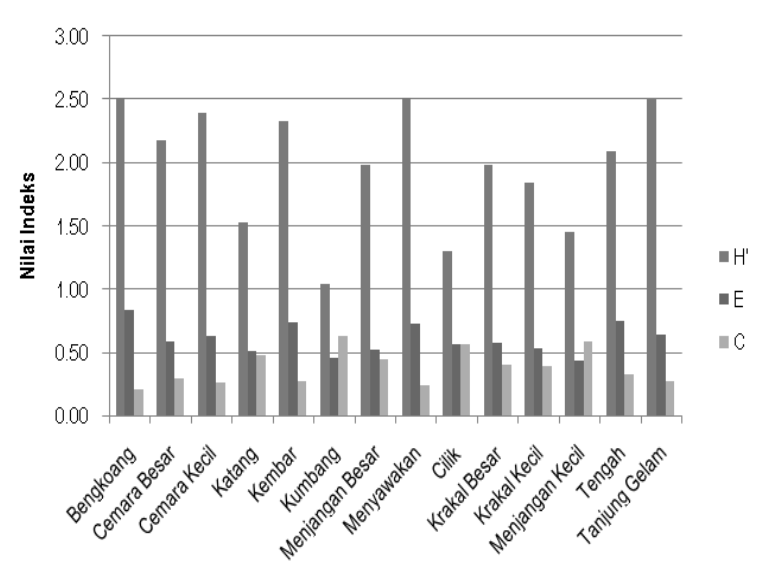

Gambar 8. Nilai indeks H', E dan C ikan pada perairan dalam.

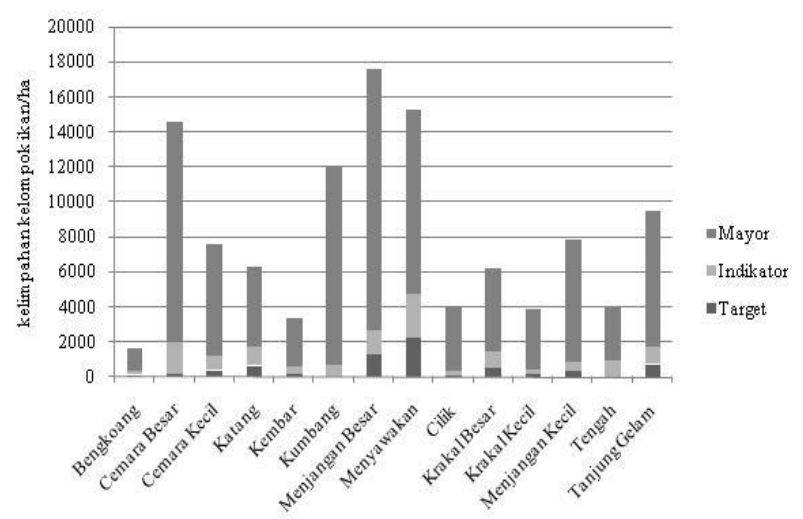

Gambar 9. Komposisi berdasarkan kelompok ikan.

Tabel 6 memperlihatkan nilai indeks keseragaman (E) antara 0,44 di pulau Menjangan Kecil sampai dengan nilai 0,84 di pulau Bengkoang. Kisaran nilai keseragaman $0,0 \leq \mathrm{E} \leq 0,5$ menunjukkan kondisi komunitas tertekan. Kondisi

Tabel 6. Struktur komunitas ikan pada perairan dalam.

\begin{tabular}{lccc}
\hline \multicolumn{1}{c}{ Lokasi } & \multicolumn{1}{c}{$\mathbf{H}^{\prime}$} & E & C \\
\hline Bengkoang & 2,51 & 0,84 & 0,21 \\
Cemara Besar & 2,18 & 0,59 & 0,29 \\
Cemara Kecil & 2,39 & 0,63 & 0,26 \\
Katang & 1,53 & 0,51 & 0,47 \\
Kembar & 2,33 & 0,73 & 0,27 \\
Kumbang & 1,04 & 0,45 & 0,63 \\
Menjangan Besar & 1,98 & 0,52 & 0,44 \\
Menyawakan & 2,51 & 0,72 & 0,24 \\
Cilik & 1,30 & 0,56 & 0,57 \\
Krakal Besar & 1,99 & 0,57 & 0,40 \\
Krakal Kecil & 1,84 & 0,53 & 0,39 \\
Menjangan Kecil & 1,45 & 0,44 & 0,58 \\
Tengah & 2,09 & 0,75 & 0,32 \\
Tanjung Gelam & 2,50 & 0,64 & 0,27 \\
\hline
\end{tabular}

Sumber : Hasil pengamatan. 
ini ditunjukkan oleh pulau Kumbang dan Menjangan Kecil. Gambr 9 memperlihatkan tidak dijumpai adanya ikan target di pulau Kumbang, 94\% ikan yang dijumpai adalah ikan mayor dan hanya 5\% ikan indikator. Pada perairan pulau Menjangan Kecil terdapat ketiga kelompok ikan, namun persentase ikan target hanya 5\% dan ikan indikator 6\% sangat kecil bila dibandingkan dengan persen ikan mayor $89 \%$.

Nilai indeks keseragaman antara $0,5 \leq \mathrm{E} \leq 0,75$ pada hampir semua pulau menunjukkan komunitas ikan karang yang labil. Komunitas labil cenderung akan mengalami perubahan secara cepat jika terjadi perubahan lingkungan. Hanya di pulau Bengkoang yang memiliki komunitas ikan karang stabil $(0,75 \leq$ $\mathrm{E} \leq 1$ ) dengan nilai indeks 0,84. Kestabilan komunitas ditandai dengan kesamaan dalam penyebaran komposisi kelompok ikan, famili yang beragam walaupun dengan kelimpahan sedikit. Indeks dominansi (C) bernilai antara 0,21-0,58. Nilai C 0,21 di pulau Bengkoang dan nilai C 0,58 pada pulau Menjangan Kecil. Menjangan Kecil didominasi oleh kelompok ikan mayor dari famili Caesionidae.

Dilihat secara letak dari gugusan kepulauan Karimunjawa, pada perairan dangkal zona pemanfaatan wisata terdapat beberapa kecenderungan sebagai berikut, pada bagian luar sebelah barat kepulauan (pulau-pulau Bengkoang, Krakal Besar, Krakal Kecil dan Tanjung Gelam) dengan kondisi terumbu karang sedang (Sulisyati dkk., 2014), dihuni oleh kelompok ikan mayor dengan sedikit famili. Pada bagian tengah kepulauan yaitu pulau Cemara Besar, Katang, Menjangan Kecil, Cemara Kecil, Menyawakan dan Menjangan Besar dengan ikan paling banyak dijumpai dengan beragam famili. Pada pulau terluar sebelah barat dan timur (pulau Kembar, Kumbang, Cilik dan Tengah) terdapat dominasi ikan karang dari sedikit famili.

Karakteristik ekosistem terumbu karang digunakan untuk menentukan aktivitas wisata yang akan dilakukan. Perairan dangkal pada pulau-pulau luar gugusan kepulauan berhadapan dengan laut lepas. Perairan yang demikian berpengaruh pada arah arus masuk dan keluar. Perairan yang berarus selat berbahaya bagi pemula. Dengan kondisi perairan berarus dan famili ikan yang relatif sedikit tidak sesuai untuk snorkeling maupun selam pemula. Bagi penyelam pemula kenyamanan dalam melakukan aktivitas lebih utama dibanding dengan tantangan yang dihadapi. Pulau-pulau yang berada di tengah gugusan kepulauan sesuai untuk wisata snorkeling. Pada lokasi paling banyak dijumpai ikan dengan beragam famili. Pulau yang berada di tengah tidak terlalu berpengaruh besar terhadap arus, gelombang dan pasang surut karena terhalangi oleh pulau-pulau di bagian barat dan timur (Hikmah, 2009).

Pada perairan dalam zona pemanfaatan wisata menunjukkan karakter perairan dengan tutupan karang kategori rendah dan ikan karang dijumpai dari sedikit famili, yaitu pulau-pulau Bengkoang, Kembar, Menyawakan, Katang dan Tengah. Karakter lain adalah tutupan karang kategori sedang dengan famili ikan melimpah berada pada pulau Cemara Besar, Cemara Kecil, Menjangan Besar dan Tanjung Gelam. Untuk karakter dari tutupan karang kategori baik yaitu dengan famili ikan sedikit ditunjukkan oleh pulau Kumbang, Krakal Kecil dan Cilik. Selanjutnya adalah tutupan karang kategori baik dengan ikan bermacam famili pada pulau Krakal besar dan Menjangan Kecil. Aktivitas wisata yang bisa dilakukan pada perairan dalam adalah diving untuk pemula dan advanced. Diving pemula dilakukan pada pulau-pulau dengan resiko penyelaman rendah dan sedikit famili, sementara untuk advanced dilakukan pada pulau-pulau dengan sumberdaya tinggi dan beragam famili ikan.

\section{KESIMPULAN}

Semua lokasi pengamatan memiliki kelimpahan ikan sedang dengan kondisi komunitas tertekan hingga stabil. Pada perairan dangkal terbagi pulau bagian luar sebelah barat kepulauan dihuni oleh kelompok ikan mayor dengan sedikit famili; bagian tengah kepulauan dengan perjumpaan ikan dari beragam famili dan pulau terluar sebelah barat dan timur terdapat dominasi ikan karang. Perairan dangkal pada pulau-pulau luar gugusan kepulauan sesuai untuk penyelam pemula. Pulau-pulau yang berada di tengah gugusan kepulauan sesuai untuk wisata snorkeling.

Pada perairan dalam karakter perairan ditunjukkan dengan tutupan karang kategori rendah dan ikan karang dijumpai dari sedikit famili, tutupan karang kategori sedang dengan famili ikan melimpah, tutupan karang kategori baik tetapi famili ikan sedikit serta tutupan karang kategori baik dengan ikan bermacam famili. Aktivitas wisata yang bisa dilakukan pada perairan dalam adalah diving untuk pemula dan advanced. Diving pemula dilakukan pada pulau-pulau dengan resiko penyelaman rendah dan sedikit famili, sementara untuk advanced dilakukan pada pulau-pulau dengan sumberdaya tinggi dan beragam famili ikan.

\section{UCAPAN TERIMAKASIH}

Kepada Ir. M.G. Nababan atas ketulusannya memotivasi tiada henti dan kepada seluruh anggota Tim Karang TN Karimunjawa atas segalanya, 
khususnya kepada Endang Abdul Rahman, Mulyadi dan Zainul.

\section{DAFTAR PUSTAKA}

Adrim, M., Harahap, S., dan Wibowo, K., 2012. Struktur Komunitas Ikan Karang di Perairan Kendari. Ilmu Kelautan, 17(3):154-163.

Anonim, 1999. Survei Kondisi Terumbu Karang, Mangrove dan Rumput Laut di Daerah Pesisir Pantai Desa Airbuana, Kahuku, Rumbia Minanga, Sapa dan Boyong Pante Kab. Minahasa Sulawesi Utara. Fakultas Perikanan dan Ilmu Kelautan Universitas Sam Ratulangi, Manado.

Burke, L., Selig, L., dan Spalding, M., 2002. Reefs at Risk in Southeast Asia. World Resourses Institute, Washington.

Clayton, A., 2002. Strategies for Sustainable Tourism Development: The Role of The Concept of Carrying Capacity. Social and Economic Studies, 51(1):61-98.

Dearden, P., Bennet, M., dan Rollins, R., 2006. Implications for Coral Reef Conservation of Diver Spesialization. Environmental Conservation, 33(4):353-363.

English, S., Wilkinson, C., dan Baker, V., 1997. Survey Manual for Tropical Marine Resources, Australian Institute of Marine Science. Townsville

Green, Stuart J.; White, Alan T.; Christie, Patrick; Kilarski, Stacey; Meneses, A.B.T.; SamonteTan, G.; Karrer, L.B.; Fox, H.; Campbell, S.; Claussen, J.D., 2011. Emerging Marine Protected Area Networks in Coral Triangle: Lessons and Way Forward. Conservation and Society, 9(3):177-188.

Hikmah, R., 2009. Kerusakan Terumbu Karang di Kepulauan Karimunjawa. Skripsi. Universitas Indonesia. Jakarta.

Kuiter, R., dan Tonozuka, T., 2001. Indonesian Reef Fishes. PT Dive \& Dave's, Victoria.

Ludwig, J., dan Reynold, J., 1988. Statistical Ecology A Primer on Methods and Computing. John Wiley \& Sons, Ontario.

Marnane, M.J., Ardiwijaya, R.L., Herdiana, Y., Pardede, S.T., dan Haryanta, S., 2003. Perbaikan Manajemen melalui Riset dan Peningkatan Kapasitas di Taman Nasional Karimunjawa dan Sekitarnya Ringkasan Data Ekologi. WCS Indonesia Marine Program. Bogor.
Marnane, M., Ardiwijaya, R., Wibowo, J., Pardede, S., Kartawijaya, T., dan Herdiana, Y., 2005. Laporan Teknis Survei 2003-2004 di Kepulauan Karimunjawa, Jawa Tengah. Wildlife Conservation Society - Marine Program Indonesia. Bogor.

Marsaoli, M., 1998. Hubungan Persentase Penutupan Karang Hidup dengan Densitas Beberapa Jenis Ikan Karang di Perairan Kepulauan Karimunjawa, Jepara. Tesis. Institut Pertanian Bogor. Bogor.

McClanahan, T.R., 2002. The Near Future of Coral Reefs. Environmental Conservation, 29(4):460-483.

Muttaqin, E., Pardede, S., Kartawijaya, T., dan Muhidin, 2013. Laporan Teknis: Monitoring Ekosistem Terumbu Karang Taman Nasional Karimunjawa Tahun 2012. Wildlife Conservation Society - Marine Program Indonesia. Bogor.

Nybakken, J.W., 1993. Marine Biology: An Ecological Approach (3 ed.). Harper Collins College Publishers. New York.

Sale, P., 1991. The Ecology of Fishes on Coral Reefs. Academic Press. California.

Salm, R.V., Clark, J., dan Siirila, E., 2000. Marine and Coastal Protected Areas: A Guide for Planner and Managers (third ed.). Washington DC: International Union for Conservation Nature, $x x i+371 p p$.

Sangadji, I., 2002. Kajian Pengembangan Kawasan Konservasi Terumbu Karang di Pulau Waidoba Kecamatan Kayoa. Tesis. Institut Pertanian Bogor. Bogor.

Sembiring, A., 2011. Distribusi Spasial Ikan Karang dan Hubungannya dengan Terumbu Karang (Kasus Perairan Bahadopi, Teluk Tolo Kabupaten Morowali Provinsi Sulawesi Tengah) Tesis. Institut Pertanian Bogor. Bogor.

Sulisyati, R., Poedjirahajoe, E., Rahayu, L., dan Fandeli, C., 2014. Karakteristik Terumbu Karang di Zona Pemanfaatan Taman Nasional Karimunjawa. Ilmu Kelautan, 19(3):139-148.

Veron, J., 1993. A Bibiographic Database of Hermatypic Corals. Aust. Inst. Mar. Sci. Monograph Series, 10:433.

Veron, J., 2000. Corals of The World. Australian Institute of Marine Science. Townsville. 